\title{
Long-term spatiotemporal genetic structure of an accidental parasitoid introduction, and local changes in prevalence of its associated Wolbachia symbiont
}

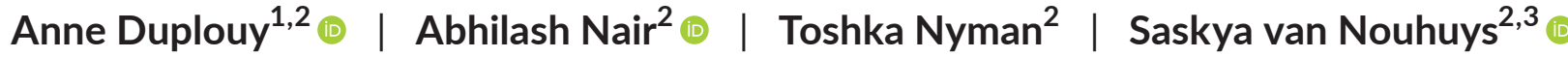

\author{
${ }^{1}$ Department of Biology, Lund University, \\ Lund, Sweden \\ ${ }^{2}$ Organismal and Evolutionary Biology \\ Research Program, The University of \\ Helsinki, Helsinki, Finland \\ ${ }^{3}$ Department of Ecology and Evolutionary \\ Biology, Ithaca, New York, USA

\section{Correspondence} \\ Anne Duplouy, Department of Biology, \\ Lund University, Lund, Sweden. \\ Emails: anne.duplouy@biol.lu.se; anne. \\ duplouy@helsinki.fi
}

Funding information

Academy of Finland, Grant/Award

Number: 255553 and 266021

\begin{abstract}
Population bottlenecks associated with founder events strongly impact the establishment and genetic makeup of populations. In addition to their genotype, founding individuals also bring along parasites, as well as symbionts that can manipulate the phenotype of their host, affecting the host population establishment, dynamics and evolution. Thus, to understand introduction, invasion, and spread, we should identify the roles played by accompanying symbionts. In 1991, the parasitoid wasp, Hyposoter horticola, and its associated hyperparasitoid were accidentally introduced from the main Åland islands, Finland, to an isolated island in the archipelago, along with their host, the Glanville fritillary butterfly. Though the receiving island was unoccupied, the butterfly was present on some of the small islands in the vicinity. The three introduced species have persisted locally ever since. A strain of the endosymbiotic bacterium Wolbachia has an intermediate prevalence in the parasitoid $H$. horticola across the main Åland population. The infection increases its susceptibility of to hyperparasitism. We investigated the establishment and spread of the parasitoid, along with patterns of prevalence of its symbiont using 323 specimens collected between 1992 and 2013 , from five localities across Åland, including the source and introduced populations. Using 14 microsatellites and one mitochondrial marker, we suggest that the relatively diverse founding population and occasional migration between islands might have facilitated the persistence of all isolated populations, despite multiple local population crashes. We also show that where the hyperparasitoid is absent, and thus selection against infected wasp genotypes is relaxed, there is near-fixation of Wolbachia.
\end{abstract}

KEYWORDS

endosymbiosis, gene flow, genotyping, Melitaea cinxia, Mesochorus stigmaticus, trophic chain

\section{1 | INTRODUCTION}

Introduced and invading populations generally show low genetic variability, and a different genetic structure than in their native range, due to small founder populations, and demographic bottlenecks (Hufbauer et al., 2004). Low genetic variability may in turn influence persistence, population dynamics, and evolutionary potential of introduced populations (Fauvergue et al., 2012; Szucs

This is an open access article under the terms of the Creative Commons Attribution-NonCommercial-NoDerivs License, which permits use and distribution in any medium, provided the original work is properly cited, the use is non-commercial and no modifications or adaptations are made.

(c) 2021 The Authors. Molecular Ecology published by John Wiley \& Sons Ltd. 
et al., 2014). The individuals founding new populations may bring along various symbiotic passengers (Hurst \& Jiggins, 2005; Lu et al., 2016; Rokas et al., 2001). A common example of such a symbiont is the $\alpha$-Proteobacterium Wolbachia pipientis - a maternally inherited endosymbiotic bacterium that infects over $40 \%$ of all arthropod species (Sazama et al., 2017; Weinert et al., 2015; Zug \& Hammerstein, 2012). Wolbachia can be intimately involved in the biology of their hosts. In insects, the symbiont is known for manipulating the host reproductive system (O'Neill et al., 1997), susceptibility to predators, parasites or pathogens (Fytrou et al., 2006; Hedges et al., 2008; van Nouhuys et al., 2016; Osborne et al., 2012), metabolism (Gruntenko et al., 2017, 2019), or dispersal capacities (Evans et al., 2009). Wolbachia-mediated costs and benefits have been shown to affect host population dynamics (Charlat et al., 2009; Duplouy et al., 2010; Verne et al., 2012), select for particular host genotypes (Signor, 2017), or even hamper the evolution of host traits in infected populations (Martinez et al., 2016). Consequently, studying spatiotemporal patterns in the penetrance and prevalence of symbionts in host populations along with the genetic structure of introduced and original host populations, can provide crucial insights into how both intentionally and accidentally introduced species may successfully establish, persist and further spread across habitats (Lu et al., 2016).

The Glanville fritillary butterfly, Melitaea cinxia (L.) (Lepidoptera: Nymphalidae) lives as a metapopulation in Åland, Finland (Hanski et al., 1995). The (meta)population ecology and dynamics of the butterfly and associated community of parasitoid species has been extensively studied since the early 90s (van Nouhuys \& Hanski, 2005). The butterfly population dynamics dictates the population sizes of its associated parasitoids (van Nouhuys \& Hanski, 2002). In August 1991, 72 sibling groups of gregarious M. cinxia larvae were intentionally introduced from Finström, on the main Åland island, on to the previously unoccupied island of Sottunga, on the East side of the Åland archipelago (Figure 1a). The introduction was part of an experiment to manipulate the butterfly metapopulation dynamics (Fountain et al., 2018; Hanski et al., 2004, 2017). The introduced butterfly larvae were collected from natural populations that were occupied by larval parasitoids. Consequently, the specialist parasitoid wasp Hyposoter horticola (Gravenhorst) (Hymenoptera: Ichneumonidae: Campoplaginae), some of which were parasitized by their own specialist hyperparasitoid Mesochorus cf. stigmaticus (Hymenoptera: Ichneumonidae: Mesochorinae) (Hanski et al., 2004; Lei et al., 1997; Montovan et al., 2015; van Nouhuys \& Ehrnsten, 2004; Shaw et al., 2009) were accidentally introduced to Sottunga along with the butterfly larvae.

Parasitoids are at the highest trophic levels of insect communities, which makes them extremely sensitive to the spatiotemporal dynamics and structure of their host resources in the landscape (Cronin \& Reeve, 2005; Gagic et al., ,2011, 2012; Kaartinen \& Roslin, 2011; Nair et al., 2016; van Nouhuys, 2005). Nonetheless, despite occasional strong bottlenecks through local butterfly population crashes in which the population declined to a few gregarious larval butterfly families (Figure 2) (van Bergen et al., 2020; Fountain
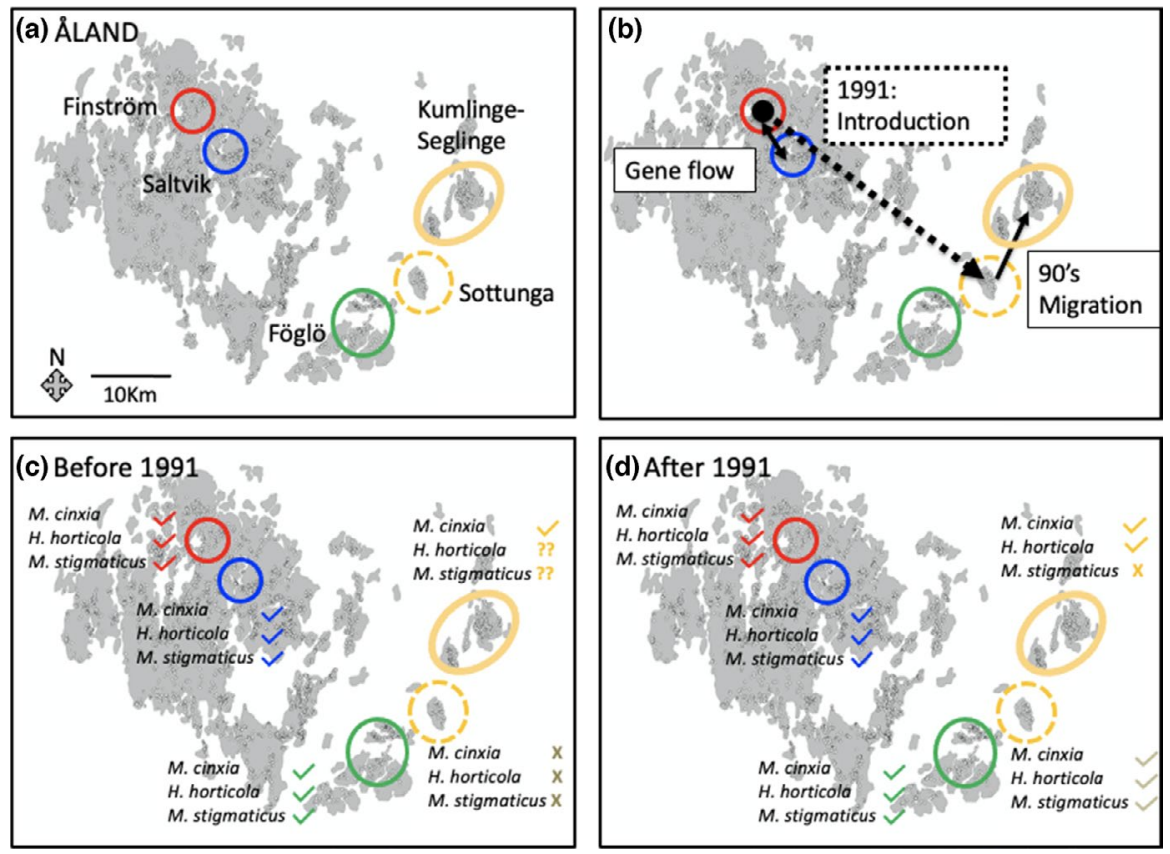

FIG URE 1 The study system evolves on the Åland archipelago, which stands in the Baltic Sea, between the coasts of Finland and Sweden. (a) Samples used in the study originated from the five local communes of Finström (red), Föglö (green), Seglinge-Kumlinge (yellow), Saltvik (blue) and Sottunga (dashed-yellow). The habitat patches of this insect community have been studied since 1990 (Ojanen et al., 2013). (b) Melitaea cinxia caterpillars that were parasitized by Hyposoter horticola and the hyperparasitoid Mesochorus cf. stigmaticus were introduced to Sottunga (dashed yellow) from Finström (red) in 1991, and specimens of $H$. Horticola succesfully migrated to Seglinge-Kumlinge later in the 90's. (c, d) The geographic distribution in Åland of the three species of this insect community changed after 1991. 'X':absent, 'V': present, and '??': unknown 
et al., 2016; Hanski et al., 2004), the parasitoids have persisted on Sottunga, which is more than $30 \mathrm{~km}$ away from the main Åland island (hereafter referred to as the mainland), and more than $12 \mathrm{~km}$ away from any other small island population. Based on mark recapture studies, pattern of colonization of new sites, and analyses of gene flow based on genetic markers, the islands are outside the usual dispersal distances of the butterfly (van Nouhuys \& Hanski, 2002), the parasitoid (Couchoux et al., 2016), and the hyperparasitoid (Nair et al., 2016).

In the Åland system Wolbachia only infects the parasitoid wasp H. horticola (Duplouy et al., 2015) and the infection occurs at an intermediate and stable rate of $\approx 50 \%$ of the wasp population (Duplouy et al., 2015). The local prevalence of the bacterium however differs between the mainland and neighbouring isolated islands, and the infection is more often associated with one of two mitochondrial host haplotypes (Duplouy et al., 2015). Finally, the infection is not known for manipulating its host reproductive system either through cytoplasmic incompatibility or any other sex-ratio distorting phenotypes, and it has no direct impact on several other fitness traits of the wasps, including metabolic rate, longevity and egg production (Duplouy et al., 2015). The infection is nonetheless costly to its host, as it increases the susceptibility of infected individuals to $M$. cf. Stigmaticus hyperparasitoid nearly two-fold (from 40\% to 74\% parasitism) (van Nouhuys et al., 2016); perhaps by decreasing the mobility of the larval wasp in the host, or by decreasing the host immune response to the hyperparasitoid (van Nouhuys et al., 2016). The prevalence and rate of hyperparasitism varies across local populations in Åland (Montovan et al., 2015; Nair et al., 2016).

We analysed spatiotemporal variations in both the genetic structure of the parasitoid, $H$. horticola, and the infection rate of the parasitoid by the endosymbiont Wolbachia on the island of Sottunga, and four other regions in the Åland islands (Figures $1 a-b)$. We used 14 nuclear microsatellite markers and one mitochondrial marker to genotype 323 wasps and screened the wasps for infection with Wolbachia over a 22year period (1992-2013), to infer history and outcome of the accidentally introduced small population for the host and the symbiont. We investigated (i) whether migration occurred after the accidental introduction of the parasitoid species to the island of Sottunga, potentially supporting persistence of the neighbouring island populations despite occasional population crashes (van Bergen et al., 2020; Fountain et al., 2016; Hanski et al., 2004), and (ii) whether the local absence of the hyperparasitoid selected for Wolbachia-infected host genotypes.

\section{2 | MATERIALS AND METHODS}

\section{1 | Insect material}

The entire metapopulation of the Glanville fritillary butterfly (Melitaea cinxia, L.) in the Åland archipelago, Southwest Finland $\left(60^{\circ} 13^{\prime} \mathrm{N} 19^{\circ} 55^{\prime} \mathrm{E}\right.$, Figure 1), has been surveyed for more than two decades as part of a long-term ecological study of its metapopulation dynamics (Ojanen et al., 2013). The Åland butterfly metapopulation presents year-to-year fluctuations. The Åland butterfly metapopulation size fluctuates greatly over time (Hanski, 2011). For instance, during the 1993-2014 period covered by this study, a minimum of 1,176 larval nests were recorded in 1997, and a maximum of 11,129 larval nests were recorded in 2012 (van Bergen et al., 2020). Caterpillars and the larval parasitoids and hyperparasitoids in them were collected occasionally from each of the regions in the 1990s, and early 2000s, and were systematically collected as part of the annual survey starting in 2008 (Fountain et al., 2016; Hanski, 2011). About a third of the field collected caterpillars are naturally parasitized by the solitary endoparasitoid wasp $\mathrm{H}$. horticola, some of which in turn are hyperparasitized by M. stigmaticus (Montovan et al., 2015; van Nouhuys \& Hanski, 2005; Shaw et al., 2009). About half the $H$. horticola in Åland are infected by Wolbachia (Duplouy et al., 2015; van Nouhuys et al., 2016).

Before 1991 (Figure 1c), the Glanville fritillary butterfly was absent from Sottunga but was known to inhabit nearby islands of Föglö, Seglinge and Kumlinge (Hanski et al., 2004; Lei \& Hanski, 1998; Murphy et al., 2004). The parasitoid and the hyperparasitoid did not inhabit Sottunga, and there was no evidence of the species being on Seglinge-Kumlinge (van Nouhuys, 2016; van Nouhuys \& Hanski, 2005). Since 1991, despite going through occasional strong local population bottlenecks (Figure 2), the butterfly (Fountain et al., 2016), the parasitoid (Couchoux et al., 2016), and the hyperparasitoid (Nair et al., 2016) have persisted in Sottunga and Föglö, and both the butterfly and pasitoid have as well persisted in SeglingeKumlinge (Figure 1).

We selected $323 \mathrm{H}$. horticola parasitoid individuals, including both males and females, reared from different butterfly host nests sampled from five localities in the Åland archipelago between 1992 and 2014 (Ojanen et al., 2013). The butterfly and its parasitoids are not classified as endangered or protected and hence no permits are required for their collection in the Åland Islands. In total, we used 40 wasps from the island of Sottunga $\left(60^{\circ} 07^{\prime} \mathrm{N}\right.$ $\left.20^{\circ} 40^{\prime} \mathrm{E}\right), 43$ from the northern islands of Föglö $\left(60^{\circ} 03^{\prime} \mathrm{N} 20^{\circ} 32^{\prime} \mathrm{E}\right.$, in areas called Jyddö, Nötö, and Överö), 44 from the closely adjacent islands of Seglinge-Kumlinge $\left(60^{\circ} 14^{\prime} \mathrm{N} 20^{\circ} 46^{\prime} \mathrm{E}\right.$, 14 samples from Kumlinge, the rest from Seglinge), 95 from northern Finström $\left(60^{\circ} 32^{\prime} \mathrm{N} 19^{\circ} 95^{\prime} \mathrm{E}\right)$ and 101 from Saltvik $\left(60^{\circ} 16^{\prime} \mathrm{N} 20^{\circ} 03^{\prime} \mathrm{E}\right)$ on the main Åland island (Figure 1a). See Table 1 for sample size for each year for different populations. The chance of collecting full-siblings in this sample is low, as a previous study designed to detect siblings using samples from the same collections found very low incidence of siblings outside of those within a gregarious host group (Couchoux et al., 2015a). The coast-to-coast distances between Sottunga and Seglinge, and between Sottunga and Föglö, are of 8.5 and $6.5 \mathrm{~km}$, respectively, while the closest distance between the two suitable habitat patches on different islands is 12 and $13 \mathrm{~km}$, respectively. The distance from a mainland area to a suitable patch on Sottunga is about $30 \mathrm{~km}$. 


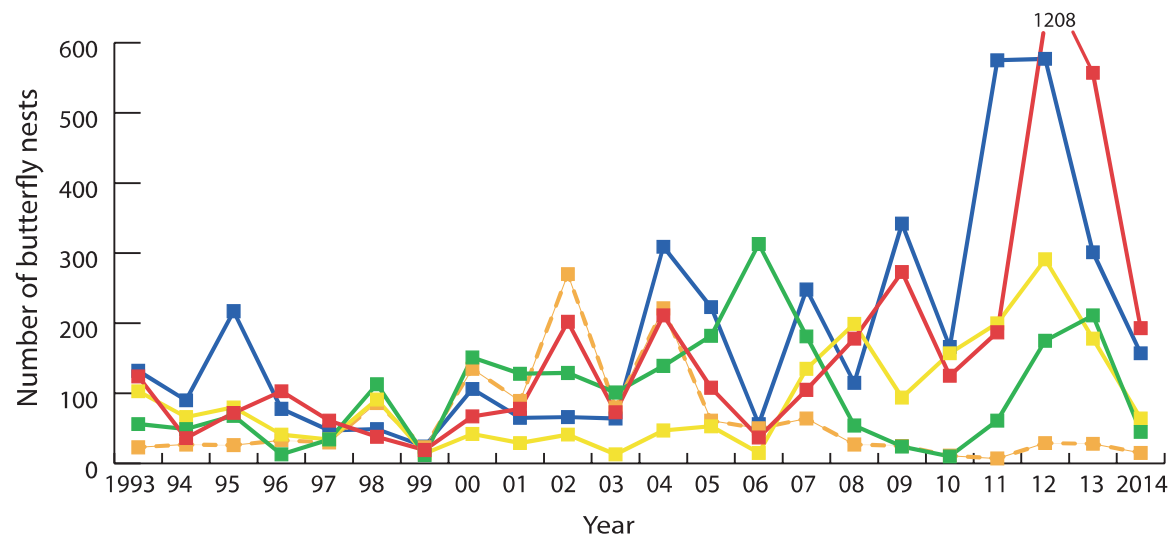

FIGURE 2 The number of nests of the Glanville fritillary butterfly, Melitaea cinxia, between 1993 to 2014 in five areas of the Åland archipelago. From highest to lowest in 2014: Finström (red), Saltvik (blue), Seglinge-Kumlinge (yellow), Föglö (green), and Sottunga (dashed yellow) (Figure adapted from data included in (Fountain et al., 2018). The number '1208' indicates the exceptional large number of nests in Finström in 2012

TAB LE 1 Sample size, observed $\left(H_{\mathrm{O}}\right)$ and expected heterozygosities $\left(H_{\mathrm{E}}\right)$, and inbreeding coefficient $\left(G_{\mathrm{is}}\right)$ for Hyposoter horticola from each locality, and penetrance of mitotype $\mathrm{C}$ and Wolbachia strain who in each locality

\begin{tabular}{|c|c|c|c|c|c|c|c|c|}
\hline Locality & $\begin{array}{l}\text { Sample size } \\
N_{\text {female }} / N_{\text {total }}\end{array}$ & \multicolumn{2}{|c|}{$\begin{array}{l}\text { Statistics } \\
\text { Females/(female + male) }\end{array}$} & $G_{\text {is }}$ & \multicolumn{4}{|c|}{ Penetrance and sample size } \\
\hline Finström & $50 / 95$ & $0.405 /(0.254)$ & $0.523 /(0.522)$ & $0.226 /(0.514)$ & 84 & $31 / 37$ & 42 & $38 / 90$ \\
\hline Föglö & $21 / 43$ & $0.277 /(0.146)$ & $0.379 /(0.413)$ & $0.270 /(0.646)$ & 95 & $39 / 41$ & 32 & $13 / 41$ \\
\hline Sottunga & $20 / 40$ & $0.345 /(0.185)$ & $0.410 /(0.383)$ & $0.158 /(0.517)$ & 71 & $27 / 38$ & 23 & $9 / 39$ \\
\hline Total & $195 / 323$ & $0.342 /(0.215)$ & $0.437 /(0.433)$ & $0.215 /(0.514)$ & 65 & $145 / 222$ & 50 & $149 / 296$ \\
\hline
\end{tabular}

Notes: Values of $H_{O}, H_{E}$ and $G_{\text {is }}$ are calculated based on diploid female data only $(N=195)$, with diploid female plus haploid male data ( $\left.N=313\right)$ in brackets. Penetrance of the mitotype- $\mathrm{C}$ and the Wolbachia infection (wHho) are based on both male and female data.

\section{2 | Sample preparation}

All $\mathrm{H}$. horticola wasps emerging from the field-collected caterpillars were individually preserved in ethanol in the freezer $\left(-20^{\circ} \mathrm{C}\right)$ until use. DNA was extracted from the abdomen of each wasp for the purpose of another study (Duplouy et al., 2015), using a Qiagen DNeasy blood and tissue extraction kit, following the manufacturer's protocol (Cat. no. 69506, Qiagen). We amplified the mitochondrial COI gene by PCR using the primer pair LCO/HCO and PCR conditions developed by Folmer et al. (1994) and included two positive samples from Duplouy et al. (2013) and a negative control to check for the quality of the DNA extracts.

\section{3 | Mitotypes and Wolbachia-infection status}

Cytoplasmic entities such as the mitochondria and Wolbachia symbionts can have profound impacts on their hosts but are passed on to the offspring only from mothers. These maternally inherited entities can thus change frequency in a population at different rates than genotypes determined using nuclear microsatellite markers. To evaluate maternal inheritance in the Åland H. horticola population, we looked at differences in the prevalence of the mitochondrion and Wolbachia-infection in most of the male and female samples genotyped in this study. For this, we used sequences of the 5'end of the mitochondrial gene $\mathrm{COI}$ and screenings of Wolbachia that were previously done by Duplouy et al. (2015). The same authors (Duplouy et al., 2015) characterized two common mitotypes (GenBank nos. KF722993 and 94, for mitotype-C and $-\mathrm{T}$, respectively) from 222 of the $323 \mathrm{H}$. horticola wasps used in the present study, including 37 individuals from Finström, 41 from Föglö, 43 from SeglingeKumlinge, 63 from Saltvik and 38 from Sottunga. The 5'end of the COI gene was Sanger sequenced with an ABI 3730 DNA Sequencer (Applied Biosystems). Additionally, Duplouy et al. (2015) showed earlier that about $50 \%$ of the $H$. horticola population on the Åland islands is infected by the Wolbachia strain wHho (ST435 from the Wolbachia-PubMLST database: Baldo et al., 2006). They screened for wHho in 296 of the 323 wasps used in this study, including 90 
from Finström, 41 from Föglö, 40 from Seglinge-Kumlinge, 86 from Saltvik and 39 from Sottunga, using the primer pair 81F/691R to amplify the conserved Wolbachia surface protein (wsp) using PCR conditions described by Zhou et al. (1998), with two positive controls from Duplouy et al. (2013) and a negative control.

\section{4 | Microsatellite genotyping}

To document temporal and spatial nuclear genetic variation in $H$. horticola, we genotyped 323 wasps including 195 females using the 14 microsatellite-loci and genotyping conditions developed by Couchoux et al. (2015b). Couchoux et al. (2015b) demonstrated that there is no linkage disequilibrium between each pair of these microsatellite loci. The forward primers were labelled with either FAM, HEX, or TAMRA fluorescent dye (DNA Technology A/S) and used in multiplex nonoverlapping PCR reactions using Qiagen Multiplex PCR kit (cat. no. 206143, Qiagen) as described by Couchoux et al. (2015b). Diluted PCR products were genotyped on an automated ABI 3730 DNA Sequencer (Applied Biosystems). The sizes were called using Genescan-500 ROX size standard. We manually curated the genotypes for each sample using the GeneMapper Software 5 (Applied Biosystems).

For the purpose of the genetic analyses described below, we separated the samples into the five localities they were collected from North Finström, North Föglö, Seglinge-Kumlinge, Saltvik or Sottunga (Figure $1 \mathrm{~b}$ ), or into 12 spatiotemporal groups according to their geographic origin and their collection time interval (Finström 1992-1997, 2003-2008, 2009-2011, Föglö 2000-2009, 20102013, Seglinge-Kumlinge 2000-2009, 2010-2011, Saltvik 1999, 2005-2009, 2010-2013, and Sottunga 2002-2004, 2005-2009; Figure 3, Table 2). Each of the 12 spatiotemporal groups was designed to include specimens from roughly either the 90 s, 2000s, and 2010s, from each locality, but due to the smaller sample size, the samples from Sottunga were divided between two temporal groups: the early and the late 2000s.

\section{5 | Data analyses}

We conducted three analyses implemented in the BAPS software (Corander et al., ,2003, 2008). Since Hymenoptera males are haploid, and females are diploid, we analysed the genetic structure of female wasps only ( $N=195)$, to avoid overestimating the impact of the haploid males. First, we ran a Bayesian clustering of individual analysis using the whole Åland as a unique population $\left(N_{\text {pop }}=1\right)$ to identify the maximum number of genetic clusters across all our samples. Then, we ran two independent spatial Bayesian clustering analyses with the "clustering of groups of individuals" ( $N_{\text {pop }}=5$ or $\left.N_{\text {pop }}=12\right)$, and with respective admixture analyses settings (Figure 3 ) to evaluate the degree of admixture at each locality, and in each locality through time. Multiple " $k$ " parameters were provided for each run and the parameter was not set as a strict limit. The Bayesian model in BAPS estimated the posterior probabilities for the optimal number of clusters (Appendices S1-S3) (Corander et al., 2003).

We used the software GENODIVE 3.04 (Meirmans \& van Tienderen, 2004) to calculate population genetics measures using only the samples that were successfully genotyped for at least seven microsatellite markers using either only diploid females $(N=195)$, or combined diploid females and haploid males data set $(N=313)$. We tested Hardy-Weinberg equilibrium at each locus in each locality, and for each of the 12 spatiotemporal groups, using the least square ANOVA method with 999 permutations (estimator $F_{\text {is }}$ given in Appendix S1C and $\mathrm{S} 3 \mathrm{C}$ ). We calculated the $F_{\mathrm{ST}}$ values between the five localities and between the 12 spatiotemporal groups. Finally, we calculated the observed $\left(H_{O}\right)$ and expected heterozygosity $\left(H_{E}\right)$ at each locus

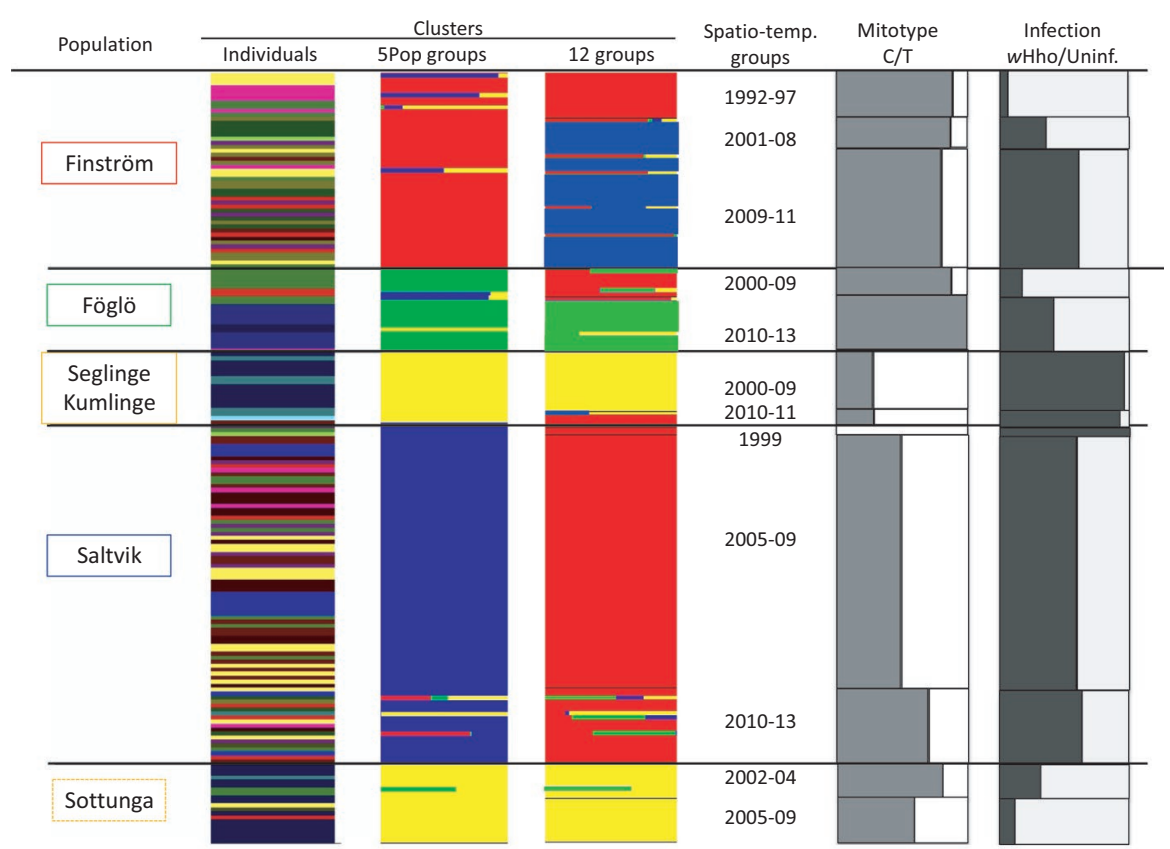

FIGURE 3 The genotypic clusters of Hyposoter horticola based on (from left to right) clustering of one whole population of individuals analysis $(k=16$, $p=0.982$ ), clustering of five groups of individuals analysis ( $k=4, p=0.999)$, and clustering of 12 spatio-temporal groups of individuals analysis $(k=4, p=0.999)$ with admixture results. The last two columns present the proportion of individual from each spatio-temporal group that carry the C-mitotype (in grey), or that are infected with Wolbachia (in dark grey). Data includes female specimens only $(N=195)$ 
TABLE 2 Genetic clusters and total sample size of the 12 spatiotemporal groups

\begin{tabular}{|c|c|c|c|c|c|c|c|c|}
\hline Locality & Period & $\begin{array}{l}\text { Clusters } \\
\text { (Figure 3) }\end{array}$ & $N=\left(N_{\text {female }}\right)$ & $H_{\mathrm{O}}$ & $H_{\mathrm{E}}$ & $G_{\text {is }}$ & \multicolumn{2}{|l|}{ Penetrance } \\
\hline Finström & $\begin{array}{r}1992- \\
98\end{array}$ & Red & $28(12)$ & $0,460(0.269)$ & $0,491(0.471)$ & $0.063(0.403)$ & $88 ., 9 \%(8 / 9)$ & $7.1 \%(2 / 28)$ \\
\hline Finström & $\begin{array}{r}2001- \\
08\end{array}$ & Green & $12(8)$ & $0.429(0.286)$ & $0.535(0.512)$ & $0.197(0.442)$ & $87.5 \%(7 / 8)$ & $\begin{array}{l}35.7 \% \\
(5 / 14)\end{array}$ \\
\hline Föglö & $\begin{array}{c}2000- \\
09\end{array}$ & Red & $18(7)$ & $0.325(0.142)$ & $0.439(0.486)$ & $0.259(0.707)$ & $\begin{array}{l}88.2 \% \\
(15 / 17)\end{array}$ & $\begin{array}{l}17.6 \% \\
(3 / 17)\end{array}$ \\
\hline Föglö & $\begin{array}{r}2010- \\
13\end{array}$ & Blue & $24(14)$ & $0.255(0.148)$ & $0.313(0.315)$ & $0.184(0.528)$ & $\begin{array}{l}100 \% \\
(24 / 24)\end{array}$ & $\begin{array}{l}41.7 \% \\
\quad(10 / 24)\end{array}$ \\
\hline Saltvik & 1999 & Red & $2(2)$ & $0.318(0.318)$ & $0.477(0.477)$ & $0.333(0.333)$ & $\begin{array}{l}0 \% \\
(0 / 2)\end{array}$ & $100 \%(1 / 1)$ \\
\hline Saltvik & $\begin{array}{c}2005- \\
09\end{array}$ & Red & $73(64)$ & $0.442(0.391)$ & $0.472(0.474)$ & $0.065(0.174)$ & $\begin{array}{l}48.7 \% \\
(19 / 39)\end{array}$ & $\begin{array}{l}59.3 \% \\
\quad(35 / 59)\end{array}$ \\
\hline Saltvik & $\begin{array}{r}2010- \\
13\end{array}$ & Red & $23(19)$ & $0.274(0.228)$ & $0.538(0.536)$ & $0.490(0.575)$ & $\begin{array}{l}69,6 \% \\
(16 / 23)\end{array}$ & $\begin{array}{l}64 \% \\
(16 / 25)\end{array}$ \\
\hline Sottunga & $\begin{array}{r}2002- \\
04\end{array}$ & Yellow & $22(9)$ & $0.304(0.126)$ & $0.367(0.372)$ & $0.172(0.660)$ & $81 \%(17 / 21)$ & $\begin{array}{l}31.8 \% \\
(7 / 22)\end{array}$ \\
\hline Sottunga & $\begin{array}{c}2005- \\
09\end{array}$ & Yellow & $18(11)$ & $0.377(0.251)$ & $0.407(0.307)$ & $0.073(0.321)$ & $\begin{array}{l}58.8 \% \\
(10 / 17)\end{array}$ & $\begin{array}{l}11.8 \% \\
(2 / 17)\end{array}$ \\
\hline
\end{tabular}

Note: Observed $\left(H_{O}\right)$ and expected heterozygosities $\left(H_{\mathrm{E}}\right)$, and inbreeding coefficient $\left(G_{\mathrm{is}}\right)$ were calculated using only the data from diploid females, with male and female data combined in brackets.

and for each locality ( $N=5)$, as well as the inbreeding coefficient $\left(G_{i s}\right)$ between each locality $(N=5)$, and each spatiotemporal group $(N=12)$ (Appendix S1B and S3B). $H_{\mathrm{O}}$ and $H_{\mathrm{E}}$ values were compared between localities using ANOVA.

To test whether samples from the Seglinge-Kumlinge islands were more often Wolbachia-infected, or carry the T-mitotype over the C-mitotype more than the rest of the Åland population, we used Fisher's exact tests for count data (two-sided) in R 3.6.3 (R Core Team, 2020).

\section{3 | RESULTS}

\subsection{Genotyping Hyposoter horticola across Åland}

After two rounds of genotyping, we successfully genotyped 7-14 microsatellite markers from 313 samples (Table S1), with majority of the samples in each spatiotemporal group being genotyped with at least 11 markers. The spatial Bayesian clustering analysis of $12 \mathrm{spa}-$ tiotemporal groups $\left(\mathrm{N}_{\mathrm{pop}}=12, \mathrm{k}=4\right.$, posterior probability $=0.999$, Appendix $1 \mathrm{~A})$, and the spatial Bayesian clustering analysis of five localities $\left(N_{\text {Pop }}=5, k=4\right.$, posterior probability $=0.999$; Appendix
$3 \mathrm{~A})$, detected only four genetically differentiated population clusters; while the Bayesian clustering analysis of female individuals $\left(N_{\text {pop }}=1\right)$ resolved to 16 genetic clusters $(k=16$, posterior probability $=0.982$, Appendix S2). Additionally, spatial Bayesian analyses including all genotyped female individuals based on either the five localities and the 12 spatiotemporal groups, show little signature of shared history (e.g., restricted gene flow) between the four clusters, and across generations, with little admixture between the different groups.

Both the five localities and the 12 spatiotemporal group analyses suggest that Sottunga and Seglinge-Kumlinge are genetically similar to one another (Figure 3). In the Bayesian clustering of localities ( $N_{\text {Pop }}=5$ ) analysis, Sottunga and Seglinge-Kumlinge populations made up one cluster ( $F_{\mathrm{ST}}=0.014, p=.045$, Table 3), and Föglö, Finström and Saltvik each made up the three other clusters (Figure 3, $F_{\mathrm{ST}}>0.05, p=.001$, Table 3). Although the clustering analysis of the 12 spatiotemporal groups generally supports the formation of these same four clusters, it also reveals more detailed spatiotemporal changes, especially in the early samples from Föglö and Finström. All samples from Saltvik, group in the same cluster (Figure 3). The two island populations of Sottunga and Seglinge-Kumlinge are always found to be genetically different from Föglö $\left(F_{\mathrm{ST}}=0.113, p=.001\right.$, 
Table 3). The samples collected in Sottunga belong to six genotypes, most of which are also found in samples collected from Finström in 1992 and 1993 (Table S1), in Seglinge-Kumlinge, and/or in other localities, thus suggesting shared ancestry of the populations. For example, the genotype " 8 " is found in two samples from Sottunga, five from Finström, eight from Saltvik, and eight from Föglö, while the genotype "15" is found in 14 samples from Sottunga, 11 from Seglinge-Kumlinge and two from Föglö (Table S1). In general, the admixture analyses revealed little interbreeding between Föglö and Sottunga or between Föglö and Saltvik, which would have been possible through dispersal through several generations, or steppingstone events, as well as dispersal over water. In contrast the analysis showed ongoing geneflow between the two mainland populations of Saltvik and Finström (Figure 3).

Consistent with Couchoux et al. (2016), we show that inbreeding occurs in Åland at similarly low levels in each of the five localities, despite the mainland populations being larger and more connected. The inbreeding coefficient $\left(G_{i s}\right)$, generally about 0.215 across Åland, ranges from 0.165 in Saltvik, to 0.270 in Föglö (Table 1; Appendix S3B); while reaching 0.206 in Sottunga (based on the diploid females data only). Although not significantly different, the values of heterozygosity are the lowest in Föglö and Seglinge-Kumlinge $\left(H_{\mathrm{o}}=0.277\right.$ and $0.284, H_{\mathrm{E}}=0.379$ and 0.383 , respectively) and the highest in Finström and Saltvik $\left(H_{0}=0.405\right.$ and $0.408, H_{E}=0.523$ and 0.488 , respectively), with Sottunga showing intermediate heterozygosity values $\left(H_{\mathrm{o}}=0.345, H_{\mathrm{E}}=0.410\right)$ (Table 1$)$. At the level of the 12 spatiotemporal groups, the three temporal groups from Finström and the three temporal groups from Saltvik also show the highest $H_{0}$ and $H_{E}$ values (i.e., generally $H_{0}>0.31$ and $H_{E}>0.47$; Table 2), but in this case, the multilocus data set for each spatiotemporal group showed that they are not all at Hardy-Weinberg equilibrium (Appendix 1C).

The parasitoid H. horticola in Åland has experienced both global and local population crashes through the years (Figure 2), some of which resulted in detectable changes in local genetic structure. For example, the genotype characterizing Föglö after the population crash of 2010 (Figure 2) is from a different genetic cluster than any of the three other clusters characterized from the other four populations. In contrast, other local crashes, for example in 1999 and 2006 in Finström, and in 1999 in Saltvik, did not seem to affect the genotypic clusters of these populations, maybe due to their presumed larger population sizes. Unfortunately, we lack data to directly address the genetic consequences of the population bottlenecks that occurred in both Seglinge-Kumlinge and Sottunga.

\section{2 | Mitochondrial haplotypes}

Finally, in agreement with a previous study by Duplouy et al. (2015), the majority of the $\mathrm{H}$. horticola parasitoids carry the C-mitotype ( $N=145,67 \%$ ), while the remaining specimens carry the T-mitotype (Table 1, Figure 3). Noticeably, the C-mitotype is prevalent in all localities (57\% in Saltvik, $71 \%$ in Sottunga, $84 \%$ in Finström, 95\% in Föglö) except Seglinge-Kumlinge (28\%) (Table 1, Figure 3). These general patterns hold across the different spatiotemporal groups (Table 2, Figure 3). The T-mitotype is significantly more prevalent in Seglinge-Kumlinge than in the rest of the Åland islands (Fisher's exact-test $p=.0001$ ), and this holds if we only take into account the wasps carrying one of the five genotypes characterized from Seglinge-Kumlinge: three wasps carry the $\mathrm{C}$-mitotype and 12 wasps carry the T-mitotype in Seglinge-Kumlinge, compared to 18 wasps carrying the C-mitotype and eight wasps carrying the T-mitotype in the rest of Åland (Fisher's exact-test $p=.0036$ ).

\subsection{Wolbachia infection status}

Wolbachia was detected in samples from all five localities. The mean infection rate across our samples is $50 \%$, which is consistent with the study of Duplouy et al. (2015), who previously investigated the prevalence of the wHho strain across the entire Åland archipelago. Among the localities, Seglinge-Kumlinge showed the highest infection rate (95\%), in great contrast with the lower infection rates of Finström (42\%), Föglö (32\%), Saltvik (59\%), and Sottunga (23\%) (Table 1, Figure 3). Wolbachia was significantly more prevalent in Seglinge-Kumlinge than in the rest of the Åland islands (Fisher's exact-test $p=.0001)$. This holds when we only consider the wasps carrying one of the five genotypes characterized from SeglingeKumlinge: one uninfected wasp and 13 Wolbachia-infected wasps characterized in Seglinge-Kumlinge, compared to 28 uninfected and 12 infected wasps in the rest of the Åland population (Fisher's exact test $p=.0001)$.

Among all Wolbachia-infected wasps sampled, 57\% carry the Tmitotype, which is equal to, or slightly lower than, the infection rate

TAB LE $3 \quad F_{\mathrm{ST}}$ values and $p$-values for all pairs of localities after pairwise differentiation analysis based on 313 samples from five localities, under and above the diagonal, respectively, with male and female data combined (1000 permutations)

\begin{tabular}{llllll}
\hline$F_{\mathrm{ST}} / p$-values & Finström & Föglö & Seglinge-Kumlinge & Saltvik & Sottunga \\
\hline Finström & - & $p=.001^{* *}$ & $p=.001^{* *}$ & $p=.001^{* *}$ & $p=.001^{* *}$ \\
\hline Föglö & 0.068 & - & $p=.001^{* *}$ & $p=.001^{* *}$ & $p=.001^{* *}$ \\
\hline Seglinge-Kumlinge & 0.124 & 0.135 & - & - & $p=.045^{*}$ \\
\hline Saltvik & 0.051 & 0.076 & 0.126 & 0.115 & $p=.001^{* *}$ \\
\hline Sottunga & 0.109 & 0.113 & $0.014^{*}$ & - & \\
\hline
\end{tabular}

Note: Bold values highlight the results of the comparison between Sottunga and Seglinge-Kumlinge. $\left({ }^{*}\right)$ Significance for $\alpha<0.05$, and $\left({ }^{* *}\right) \alpha<0.01$. 
characterized by Duplouy et al. (2015). However, the proportion of infected wasps carrying the T-mitotype differed among localities. In Saltvik, Finström and Föglö, 60\%, 33\% and 0\% of Wolbachia-infected wasps carry the T-mitotype, respectively. In contrast, Sottunga and Seglinge-Kumlinge are more similar to each other than to any other population, with the great majority of Wolbachia-infected wasps carrying the T-mitotype ( $75 \%$ and $79 \%$, respectively) rather than the C-mitotype. This is despite the two island populations showing contrasting proportions of specimens carrying the T-mitotype (see above).

\section{4 | DISCUSSION}

The introduction and long-term persistence of the parasitoid wasp $\mathrm{H}$. horticola in the small island of Sottunga, on the East side of the Åland archipelago, offered a unique opportunity to investigate the spatiotemporal changes in the genetic structure, spread, and dynamics of a parasitoid species introduced into a new habitat along with its host butterfly. Because the parasitoid carried along its Wolbachia symbiont, we could also investigate how symbionts might affect the spread of different host genotypes after introduction. Our results suggest that the $\mathrm{H}$. horticola population that established in Sottunga persisted despite strong bottlenecks during population fluctuations across its 22 years of persistence, and potentially in the founding generation. Additionally, the introduction might probably have affected the genetic pool of the population inhabiting the nearby islands through dispersal of individuals carrying the mainland genotypes, and by the establishment of populations carrying a costly Wolbachia strain.

\section{1 | Spatiotemporal genetic changes: The role of a local introduction}

In a previous study, Couchoux et al. (2016) suggested some ongoing genetic mixing between the $H$. horticola parasitoid population in Sottunga and the neighbouring northern population inhabiting the Seglinge-Kumlinge islands. Many genotypes found in the original mainland population of Finström were evident in wasps from both the Sottunga and Seglinge-Kumlinge islands. The movement of genotypes over long distances such as the one separating the islands from the mainland can occur over several generations of ongoing gene flow through interbreeding (Couchoux et al., 2016; DiLeo et al., 2018; Slarkin, 1985), but it is simply more likely that, instead, the genotypes introduced to Sottunga in 1991 have persisted over time on the island, and that dispersal between Sottunga and the islands of Seglinge-Kumlinge in the North has occurred. In contrast, the mainland genotypes are not found in $\mathrm{H}$. horticola from the southern islands of Föglö, which is about the same distance from Sottunga as Seglinge is, but further away from the mainland populations.

The coast-to-coast distances between Sottunga and the neighbouring islands of Seglinge or Föglö are at least $6.5 \mathrm{~km}$, with about
$12 \mathrm{~km}$ as the shortest distances between known suitable habitat patches on the islands (Ojanen et al., 2013). The parasitoid $H$. horticola is more dispersive than its butterfly host (van Nouhuys \& Hanski, 2002), commonly flying over $1 \mathrm{~km}$ distance, and potentially travelling up to $7.5 \mathrm{~km}$ over land within a breeding season (Couchoux et al., 2016). The flight capacity of the parasitoid allows it to disperse across unsuitable habitats on the mainland but is most likely not sufficient to cross stretches of open water separating two islands, or the $30 \mathrm{~km}$ separating the mainland from the shores of Sottunga. Insects can, however, move across large unsuitable habitats under prevailing winds (Compton, 2002; Pasek, 1988). In the Baltic Sea, a dominant wind blowing from the South (Bierstedt et al., 2015) could transport wasps from North Sottunga to Seglinge-Kumlinge, as well as inhibit southward movements towards Föglö. Insects can also be moved by humans intentionally or incidentally (Kritani \& Yamamura, 2003). One of the host plants of the Glanville fritillary butterfly, Veronica spicata (Kuussaari et al., 2004) produces indigo blue flower spikes that may be of interest to gardeners on the different islands. The human-assisted migration of $\mathrm{H}$. horticola within their host caterpillars feeding on plants (Carlsson et al., 2014), although possible, has not been suggested from any population genetic studies conducted on the Åland butterfly populations (Fountain et al., ,2016, 2018), and is thus thought unlikely.

While the butterfly was known to occupy Seglinge-Kumlinge prior to year 2000, there is no local historical record of the parasitoid $H$. horticola, and we did not find any unique genotypes nor mitotypes in those islands. Rather, the current parasitoid population on Seglinge-Kumlinge resembles to the introduced parasitoids from Sottunga, suggesting that $H$. horticola from Sottunga may have colonized Seglinge-Kumlinge. If this is true, prior to the $H$. horticola introduction, the Seglinge-Kumlinge butterfly population may have been free of the parasitoid. This is significant for the butterfly because where present, $H$. horticola parasitizes about $30 \%$ of the host larvae (Montovan et al., 2015). To date, it remains unclear whether the introduction of the parasitoid to Seglinge-Kumlinge, where the butterfly may have persisted without a specialist parasitoid, has had any influence on the ecoevolutionary dynamics of this local butterfly population.

There are many examples of the effect of isolation on the genetics of introduced Island populations (Hufbauer et al., 2004; Mattila et al., 2012; Miller et al., 2011; Szucs et al., 2014; Urquia et al., 2019), including a study of human population on the island of Sottunga (O'Brien et al., 1988). Generally, these small and isolated populations show low allelic diversity, low heterozygosity and high inbreeding values (Fauvergue et al., 2012; Mattila et al., 2012; Nei et al., 1975). The Sottunga population of the parasitoid $\mathrm{H}$. horticola, as well as the isolated populations of Föglö and of Seglinge-Kumlinge, show slightly lower observed heterozygocity $\left(H_{\circ} \approx 0.3\right)$ than the large mainland Åland populations $\left(H_{0} \approx 0.4\right)$. This is probably due to loss of genetic diversity in the islands following local population crashes. However, heterozygosity remains relatively high compared to studies from other similarly isolated animal populations (Fountain et al., 2016; O'Brien et al., 1988; Sarhan \& Kokko, 2007), which may be due 
to the relatively large founding populations of 71 larval hosts nests. Most of these nests would have contained $H$. horticola from different families (Couchoux et al., 2015a). The processes of species invasion as well as intentional introduction for biological control are often hindered by the genetic consequences of small founding populations (Fauvergue et al., 2012; Hufbauer et al., 2004, 2013). Furthermore, while there is some evidence of occasional strong inbreeding $\left(F_{\text {is }}\right.$ values Appendix 1c), all five populations show similar degrees of overal inbreeding without strong differences between mainland and island populations $\left(G_{i s}=0.18\right.$ and 0.23 in the mainland populations, while $G_{\text {is }}$ values vary between 0.21 and 0.24 in the three island populations). Rapid population growth after bottleneck and high dispersive ability are known to counteract the effect of small population size and isolation on both the loss of heterozygosity and inbreeding ( $\mathrm{Nei}$ et al., 1975), and our study might represent such example of a clear ancestry being still visible despite local bottlenecks and long-term isolation of some populations.

\section{2 | Spatiotemporal genetic changes: The effect of Wolbachia infection}

Endosymbionts, such as Wolbachia, are selfish entities that have evolved to promote their own prevalence in their host populations through increasing the fitness of the infected individuals over their uninfected counterparts (O'Neill et al., 1997). The success of symbioses is, however, often context-dependent (Ferrari \& Vavre, 2011; Hajek et al., 2019). While the Wolbachia strain wHho occurs at an intermediate prevalence across the Åland Islands (Duplouy et al., 2015), on the islands of Seglinge-Kumlinge, it has been almost at fixation since the year 2000, and potentially earlier. As shown by Duplouy et al. (2015), this Wolbachia strain appears not to affect dispersal capacity of $\mathrm{H}$. horticola, thus the high Wolbachia prevalence in Seglinge-Kumlinge is unlikely to be due to differential dispersal of infected wasps to these islands. However, Wolbachia increases the susceptibility of the wasp $\mathrm{H}$. horticola to hyperparasitism by the hyperparasitoid Mesochorus cf. stigmaticus (van Nouhuys et al., 2016). The hyperparasitoid is common across the Åland mainland (Nair et al., 2016), and is also present in Sottunga and Föglö, but is absent from Seglinge-Kumlinge islands (van Nouhuys \& Hanski, 2005). The hyperparasitoid wasp restrains the spread of $w \mathrm{Hho}$ in $\mathrm{H}$. horticola by keeping the infection at lower prevalence when highly abundant (van Nouhuys et al., 2016). Thus, the absence of M. cf. stigmaticus in Seglinge-Kumlinge (Nair et al., 2016; van Nouhuys \& Hanski, 2005; van Nouhuys et al., 2016) releases the selection pressure on wHhoinfected $H$. horticola wasps, and allows the spread of the symbiont in this isolated wasp population (van Nouhuys et al., 2016). Although primarily vertically transmitted, Wolbachia has been suggested to occasionally transfer horizontally between hosts, with parasitoids being one of the suggested ecological routes supporting such transfer (Duplouy et al., 2020; Vavre et al., 1999). Mesochorus cf. stigmaticus wasps are however not known to carry Wolbachia, nor to vector the symbiont between hosts in the Åland population of their food web insect community (based on microbiota data from the butterfly host Duplouy et al., 2018, 2020, and from the screening of over $N=200$ specimens of both the butterfly and the hyperparasitoid species by the first author, Duplouy, personal observation).

The spread of a maternally inherited symbiont, such as Wolbachia, leads to a simultaneous increase in prevalence of the host mitochondrial haplotypes associated with the symbiont (Charlat et al., 2009; Duplouy et al., 2010; Schuler et al., 2016). In H. horticola in Åland, both C- and T-mitotypes associate with the wHho infection. The Cmitotypes are however less associated with the infection, potentially because the trans-generation transmission of this Wolbachia strain is less efficient in females carrying the $\mathrm{C}$ - over the T-mitotype (Duplouy et al., 2015). Consequently, we expected that the T-mitotype would be found at low frequency in Seglinge-Kumlinge, as it was in the original population of Finström (16\%), as well as in Sottunga (29\%). Instead, we found that the T-mitotype is prevalent in SeglingeKumlinge (72\%). The spread of the wasps carrying the T-mitotype in Seglinge-Kumlinge could result from: (a) the selective sweep of the T-matriline during the spread of Wolbachia in Seglinge-Kumlinge in the absence of pressures from the hyperparasitoid, (b) strong bottlenecks randomly selecting for individuals from the T-matriline over the C-matriline in Seglinge-Kumlinge during migration events from Sottunga, and (c) uncharacterized fitness benefits associated with the T- mitotype. According to our data, Seglinge-Kumlinge has been colonized by several genotypes found in the rest of Åland, which suggests that several migration events have occurred between the two populations over the 22 year period of our study. This rate of migration considerably reduces the probability of a high frequency of the T- mitotype in Seglinge-Kumlinge due to bottlenecks, especially because the $\mathrm{C}$-mitotype is significantly more prevalent in the potential source population of Sottunga. It is thus more likely that selection acts on the wasps after migration in Seglinge-Kumlinge. Additionally, there is currently no evidence that the T-mitotype provides any benefit to its host that the C-mitotype would not, and it remains generally rare across Åland (Duplouy et al., 2015). Consequently, the high prevalence of the T-mitotype in Seglinge-Kumlinge is most likely due to the spread of the associated $w \mathrm{Hho}$ under relaxed pressures of the hyperparasitoid.

\subsection{Conclusion}

The study of invasion and of accidental or intentional introductions of species are central to much of contemporary population and community ecology (Davis, 2009; Lockwood et al., 2013). Parasitoids are used as insect biological control agents (Wang et al., 2019). Consequently, they are intentionally introduced into both agricultural and natural environments (Grangirard et al., 2009). These introductions, however, do not always persist in the long term (Goldson et al., 2014), and if they do, their genetic structure both bares the signature of the origin and differs from it (Hufbauer et al., 2004). Associated symbionts brought along during the introduction events can impact the success story of their host populations by affecting 
the phenotypes and genotypes of their hosts (Charlat et al., 2009; Hornett et al., 2006). We use genetic evidence to document the trajectory of a successfully introduced parasitoid population over 22 years. We show persistence of the wasp on the previously uninhabited island, and spread of the transplanted genotypes to surrounding islands, along with the associated symbiotic bacterium Wolbachia. The shuffling of the nuclear and matrilineally inherited markers among islands suggests differential selection for the infection-associated genotypes in the local host genetic pools under relaxed parasitism pressures on an island where the hyperparasitoid species is absent (van Nouhuys et al., 2016). The invasion by newly introduced parasitoid genotypes might contribute to either the persistence of the isolated island wasp populations, or the replacement of the local wasp populations, or both. It may have also changed environment for the pre-existing nearby isolated butterfly host population, which previously did not have the parasitoid. Like many other butterfly and insect species, the Glanville fritillary butterfly is vulnerable to loss of genetic variability and extinction in the Baltic Sea region due to habitat fragmentation, and is extinct from the Turku archipelago in southwest Finland (Fountain et al., 2016). The spread of an introduced parasitoid population can represent another pressure for such host populations, as well as any competing local parasitoid populations (Benson et al., 2003; Benvenuto et al., 2012). This is especially true if newly introduced parasitoid genotypes show greater fitness than native genotypes (Dupas et al., 2009; Kraaijeveld et al., 1998; van Nouhuys et al., 2012).

\section{ACKNOWLEDGEMENTS}

We thank C. Couchoux for advice on the genotyping work, S. Ikonen for rearing the insects, and S. Ojanen and many students from the University of Helsinki, who conducted the annual survey and collected the samples over the years. We are grateful to I. Hanski and P. Seppä for their interest in and constructive discussions on the study. This work was supported by the Academy of Finland (grant \#266021 to AD, and \#255553 to SvN). Diversity, Equality and Inclusion statement: The authors highly value equity, diversity and inclusion in science. We acknowledge the international character of our team, which significantly contributed to the completion and quality of the study. It includes researchers from different countries, backgrounds and career stages. Authors are from France, India, Hungary and USA. Three coauthors are female and one is male. We cite a large body of studies from a potentially male-biased author-list. We wish to address these DEI shortcomings in future work.

\section{CONFLICT OF INTEREST}

There are no conflicts of interest concerning this article.

\section{AUTHOR CONTRIBUTIONS}

Anne Duplouy, Abhilash Nair and Saskya van Nouhuys designed the research. Anne Duplouy and Toshka Nyman produced the data. Anne Duplouy and Abhilash Nair analysed the data. Anne Duplouy took the lead in writing the manuscript, to which all the authors contributed.

\section{DATA AVAILABILITY STATEMENT}

The data set supporting the conclusions of this article has been made available in the Zenodo repository (https://doi.org/10.5281/ zenodo.4922564); and all analyses are available in appendixes in the Supporting Information.

\section{ORCID}

Anne Duplouy (iD) https://orcid.org/0000-0002-7147-5199

Abhilash Nair (D) https://orcid.org/0000-0003-3487-1114

Saskya van Nouhuys (D) https://orcid.org/0000-0003-2206-1368

\section{REFERENCES}

Baldo, L., Hotopp, J. C., Jolley, K. A., Bordenstein, S. R., Biber, S. A., Choudhury, R. R., \& Werren, J. H. (2006). Multilocus sequence typing system for the endosymbiont Wolbachia pipientis. Applied and Environment Microbiology, 72, 7098-7110. https://doi.org/10.1128/ AEM.00731-06

Benson, J., Van Driesche, R. G., Pasquale, A., \& Elkinton, J. (2003). Introduced braconid parasitoids and range reduction of a native butterfly in New England. Biological Control, 28(2), 197-213. https://doi.org/10.1016/S1049-9644(03)00058-6

Benvenuto, C., Cheyppe-Buchmann, S., Bermond, G., Ris, N., \& Fauvergue, X. (2012). Intraspecific hybridization, life history strategies and potential invasion success in a parasitoid wasp. Evolutionary Ecology, 26, 1311-1329. https://doi.org/10.1007/s10682-011-9553-z

Bierstedt, S. E., Hünicke, B., \& Zorita, E. (2015). Variability of wind direction statistics of mean and extreme wind events over the Baltic Sea region. Tellus A: Dynamics Meteorology and Oceanography, 67(1), 29073. https://doi.org/10.3402/tellusa.v67.29073

Carlsson, R., Hæggström, C.-A., \& Sundberg, K. (2014). Ruderal vascular plants on a waste ground in the island of Dånö, Åland Islands, SW Finland. Memoranda Societatis pro Fauna Et Flora Fennica, 90, 55-66. https://www.semanticscholar.org/paper/Ruderal-vascu lar-plants-on-a-waste-ground-in-the-of-Carlsson-H\%C3\%A6ggs tr\%C3\%B6m/bd15d182e2afafb85f062fe66d1c8824e7c258f3

Charlat, S., Duplouy, A., Hornett, E. A., Dyson, E. A., Davies, N., Roderick, G. K., Wedell, N., \& Hurst, G. D. D. (2009). The joint evolutionary histories of Wolbachia and mitochondria in Hypolimnas bolina. BMC Evolutionary Biology, 9, 64. https://doi.org/10.1186/1471-2148-9-64

Compton, S. G. (2002). Sailing with the wind: dispersal by small flying insects. In J. M. Bullock, R. E. Kenward, \& R. S. Hails (Eds.), Dispersal ecology: 42nd symposium of the British ecological society (pp. 113133). Blackwell.

Corander, J., Marttinen, P., Sirén, J., \& Tang, J. (2008). Enhanced Bayesian modelling in BAPS software for learning genetic structures of populations. BMC Bioinformatics, 9, 539.-https://doi. org/10.1186/1471-2105-9-539

Corander, J., Waldmann, P., \& Sillanpää, M. L. (2003). Bayesian analysis of genetic differentiation between populations. Genetics, 163, 367374. https://doi.org/10.1093/genetics/163.1.367

Couchoux, C., Seppä, P., \& van Nouhuys, S. (2015a). Behavioural and genetic approaches to evaluate the effectiveness of deterrent marking by a parasitoid wasp. Behaviour, 152(9), 1257-1276. https://doi. org/10.1163/1568539X-00003277

Couchoux, C., Seppä, P., \& van Nouhuys, S. (2015b). Microsatellites for the parasitoid wasp Hyposoter horticola. Conservation Genetics Resources, 7, 595-597. https://doi.org/10.1007/s1268 6-015-0437-3

Couchoux, C., Seppa, P., \& van Nouhuys, S. (2016). Strong dispersal in a parasitoid wasp overwhelms habitat fragmentation and host population dynamics. Molecular Ecology, 25(14), 3344-3355. https://doi. org/10.1111/mec.13696 
Cronin, J. T., \& Reeve, J. D. (2005). Host parasitoid spatial ecology: a plea for a landscape-level synthesis. Proceedings of the Royal Society B: Biological Sciences, 272(1578), 2225-2235. https://doi. org/10.1098/rspb.2005.3286

Davis, M. A. (2009). Invasion biology. Oxford University Press.

DiLeo, M. F., Husby, A., \& Saastamoinen, M. (2018). Landscape permeability and individual variation in a dispersal-linked gene jointly determine genetic structure in the Glanville fritillary butterfly Evolution Letters, 2(6), 544-556. https://doi.org/10.1002/evl3.90

Dupas, S., Dubuffet, A., Carton, Y., \& Poirie, M. (2009). Local, geographic and phylogenetic scales of coevolution in Drosophila-parasitoid interactions. Advances in Parasitology, 70, 281-295. https://doi. org/10.1016/S0065-308X(09)70011-9

Duplouy, A., Couchoux, C., Hanski, I., \& van Nouhuys, S. (2015). Wolbachia Infection in a Natural Parasitoid Wasp Population. PLoS One, 10(8), e0134843. https://doi.org/10.1371/journal.pone.0134843

Duplouy, A., Hurst, G. D., O'Neill, S. L., \& Charlat, S. (2010). Rapid spread of male-killing Wolbachia in the butterfly Hypolimnas bolina. Journal of Evolutionary Biology, 23(1), 231-235. https://doi. org/10.1111/j.1420-9101.2009.01891.x

Duplouy, A., Iturbe-Ormaetxe, I., Beatson, S. A., Szubert, J. M., Brownlie, J. C., McMeniman, C. J., McGraw, E. A., Hurst, G. D. D., Charlat, S., O'Neill, S. L., \& Woolfit, M. (2013). Draft genome sequence of the male-killing Wolbachia strain wBol1 reveals recent horizontal gene transfers from diverse sources. BMC Genomics, 14, 20. https://doi. org/10.1186/1471-2164-14-20

Duplouy, A., Minard, G., Lähteenaro, M., Rytteri, S., \& Saastamoinen, M. (2018). Silk properties and overwinter survival in gregarious butterfly larvae. Ecology and Evolution, 8(24), 12443-12455. https://doi. org/10.1002/ece3.4595

Duplouy, A., Minard, G., \& Saastamoinen, M. (2020). The gut bacterial community affects immunity but not metabolism in a specialist herbivorous butterfly. Ecology and Evolution, 10(16), 8755-8769. https://doi.org/10.1002/ece3.6573

Duplouy, A., Pranter, R., Warren-Gash, H., Tropek, R., \& Wahlberg, N. (2020). Towards unravelling Wolbachia global exchange: a contribution from the Bicyclus and Mylothris butterflies in the Afrotropics. BMC Microbiology, 20(1), 319. https://doi.org/10.1186/s12866020-02011-2

Evans, O., Caragata, E. P., McMeniman, C. J., Woolfit, M., Green, D. C., Williams, C. R., \& McGraw, E. A. (2009). Increased locomotor activity and metabolism of Aedes aegypti infected with a life-shortening strain of Wolbachia pipientis. Journal of Experimental Biology, 212(Pt 10), 1436-1441. https://doi.org/10.1242/jeb.028951

Fauvergue, X., Vercken, E., Malausa, T., \& Hufbauer, R. A. (2012). The biology of small, introduced populations, with special reference to biological control. Evolutionary Applications, 5(5), 424-443. https:// doi.org/10.1111/j.1752-4571.2012.00272.x

Ferrari, J., \& Vavre, F. (2011). Bacterial symbionts in insects or the story of communities affecting communities. Philosophical Transactions of the Royal Society of London. Series B, Biological Sciences, 366(1569), 1389-1400. https://doi.org/10.1098/rstb.2010.0226

Folmer, O., Black, M., Hoeh, W., Lutz, R., \& Vrijenhoek, R. (1994). DNA primers for amplification of mitochondrial cytochrome c oxidase subunit I from diverse metazoan invertebrates. Molecular Marine Biology and Biotechnology, 3(5), 294-299.

Fountain, T., Husby, A., Nonaka, E., DiLeo, M. F., Korhonen, J. H., Rastas, P., Schulz, T., Saastamoinen, M., \& Hanski, I. (2018). Inferring dispersal across a fragmented landscape using reconstructed families in the Glanville fritillary butterfly. Evolutionary Applications, 11(3), 287-297. https://doi.org/10.1111/eva.12552

Fountain, T., Nieminen, M., Siren, J., Wong, S. C., Lehtonen, R., \& Hanski, I. (2016). Predictable allele frequency changes due to habitat fragmentation in the Glanville fritillary butterfly. Proceedings of the National Academy of Sciences, 113(10), 2678-2683. https://doi. org/10.1073/pnas.1600951113
Fytrou, A., Schofield, P. G., Kraaijeveld, A. R., \& Hubbard, S. F. (2006) Wolbachia infection suppresses both host defence and parasitoid counter-defence. Proceedings of the Royal Society B: Biological Sciences, 273(1588), 791-796. https://doi.org/10.1098/ rspb.2005.3383

Gagic, V., Hanke, S., Thies, C., Scherber, C., Tomanovic, Z., \& Tscharntke, T. (2012). Agricultural intensification and cereal aphid-parasitoidhyperparasitoid food webs: network complexity, temporal variability and parasitism rates. Oecologia, 170(4), 1099-1109. https://doi. org/10.1007/s00442-012-2366-0

Gagic, V., Tscharntke, T., Dormann, C. F., Gruber, B., Wilstermann, A., \& Thies, C. (2011). Food web structure and biocontrol in a fourtrophic level system across a landscape complexity gradient. Proceedings of the Royal Society B: Biological Sciences, 278(1720), 2946-2953. https://doi.org/10.1098/rspb.2010.2645

Goldson, S. L., Wratten, S. D., Ferguson, C. M., Gerard, P. J., Barratt, B. I. P., Hardwick, S., \& Tomasetto, F. (2014). If and when succesful classical biological control fails. Biological Control, 72, 76-79. https:// doi.org/10.1016/j.biocontrol.2014.02.012

Grangirard, J., Hoddle, M., Petit, J., Roderick, G., \& Davies, N. (2009). Classical biological control of the glassy-winged sharpshooter, Homalodisca vitripennis, by the egg parasitoid Gonatocerus ashmeadi in the Society, Marquesas and Austral archipelagos of French Polynesia. Biological Control, 48(2), 155-163. https://doi. org/10.1016/j.biocontrol.2008.10.005

Gruntenko, N. E., Ilinsky, Y. Y., Adonyeva, N. V., Burdina, E. V., Bykov, R. A., Menshanov, P. N., \& Rauschenbach, I. Y. (2017). Various Wolbachia genotypes differently influence host Drosophila dopamine metabolism and survival under heat stress conditions. BMC Evolutionary Biology, 17(252). https://doi.org/10.1186/s12862-017-1104-y

Gruntenko, N. E., Karpova, E. K., Adonyeva, N. V., Andreenkova, O. V., Burdina, E. V., Ilinsky, Y. Y., \& Rauschenbach, I. Y. (2019). Drosophila female fertility and juvenile hormone metabolism depends on the type of Wolbachia infection. Journal of Experimental Biology, 222(Pt 4). https://doi.org/10.1242/jeb.195347

Hajek, A. E., Morris, E. E., \& Hendry, T. A. (2019). Context-dependent interactions of insects and defensive symbionts: insights from a nove system in siricid woodwasps. Current Opinion in Insect Science, 33, 77-83. https://doi.org/10.1016/j.cois.2019.03.006

Hanski, I. A. (2011). Eco-evolutionary spatial dynamics in the Glanville fritillary butterfly. Proceedings of the National Academy of Sciences USA, 108(35), 14397-14404. https://doi.org/10.1073/pnas.11100 20108

Hanski, I., Ehrlich, P. R., Nieminen, M., Murphy, D. D., Hellmann, J. J., Boggs, C. L., \& McLaughlin, J. F. (2004). Checkerspots and conservation biology. In P. R. Ehrlich, \& I. Hanski (Eds.), On the wings of checkerspots: A model system for population biology. Oxford University Press.

Hanski, I., Pakkala, T., Kuussaari, M., \& Lei, G. (1995). Metapopulation persistence of an endangered butterfly in a fragmented landscape. Oikos, 72(1), 21-28. https://doi.org/10.2307/3546033

Hanski, I., Schulz, T., Wong, S. C., Ahola, V., Ruokolainen, A., \& Ojanen, S. P. (2017). Ecological and genetic basis of metapopulation persistence of the Glanville fritillary butterfly in fragmented landscapes. Nature Communications, 8, 14504. https://doi.org/10.1038/ ncomms14504

Hedges, L. M., Brownlie, J. C., O'Neill, S. L., \& Johnson, K. N. (2008) Wolbachia and virus protection in insects. Science, 322(5902), 702. https://doi.org/10.1126/science.1162418

Hornett, E. A., Charlat, S., Duplouy, A. M., Davies, N., Roderick, G. K., Wedell, N., \& Hurst, G. D. (2006). Evolution of male-killer suppression in a natural population. PLoS Biology, 4(9), e283. https://doi. org/10.1371/journal.pbio.0040283

Hufbauer, R. A., Bogdanowicz, S. M., \& Harrison, R. G. (2004). The population genetics of a biological control introduction: mitochondrial DNA and microsatellie variation in native and introduced populations of 
Aphidus ervi, a parasitoid wasp. Molecular Ecology, 13(2), 337-348. https://doi.org/10.1046/j.1365-294X.2003.02084.x

Hufbauer, R. A., Rutschmann, A., Serrate, B., Vermeil de Conchard, H., \& Facon, B. (2013). Role of propagule pressure in colonization success: disentangling the relative importance of demographic, genetic and habitat effects. Journal of Evolutionary Biology, 26(8), 1691-1699. https://doi.org/10.1111/jeb.12167

Hurst, G. D., \& Jiggins, F. M. (2005). Problems with mitochondrial DNA as a marker in population, phylogeographic and phylogenetic studies: the effects of inherited symbionts. Proceedings of the Royal Society B: Biological Sciences, 272(1572), 1525-1534. https://doi. org/10.1098/rspb.2005.3056

Kaartinen, R., \& Roslin, T. (2011). Shrinking by numbers: landscape context affects the species composition but not the quantitative structure of local food webs. Journal of Animal Ecology, 80(3), 622-631. https://doi.org/10.1111/j.1365-2656.2011.01811.x

Kraaijeveld, A. R., Van Alphen, J. J., \& Godfray, H. C. (1998). The coevolution of host resistance and parasitoid virulence. Parasitology, 116(Suppl), S29-45. https://doi.org/10.1017/s0031182000084924

Kritani, K., \& Yamamura, K. (2003). Exotic insects and their pathways for invasion. In J. Carlton (Ed.), Invasive species: vectors and management strategies (pp. 44-67). Island Press.

Kuussaari, M., van Nouhuys, S., Hellmann, J. J., \& Singer, M. C. (2004). Larval biology of checkerspots. In P. R. Ehrlich, \& I. Hanski (Eds.), On the wings of checkerspots: A model system for population biology ( $p p$. 138-160). Oxford University Press.

Lei, G., \& Hanski, I. (1998). Spatial dynamics of two competing specialist parasitoids in a host metapopulation. Journal of Animal Ecology, 67(3), 422-433. https://doi.org/10.1046/j.1365-2656.1998.00204.x

Lei, G. C., Vikberg, V., Nieminen, M., \& Kuussaari, M. (1997). The parasitoid complex attacking Finnish populations of the Glanville fritillary Melitaea cinxia (Lep: Nymphalidae), an endangered butterfly. Journal of Natural History, 31(4), 635-648. https://doi.org/10.1080/00222 939700770301

Lockwood, J. L., Hoopes, M. F., \& Marchetti, M. P. (2013). Invasion ecology. John Wiley \& Sons.

Lu, M., Hulcr, J., \& Sun, J. (2016). The role of symbiotic microbes in insect invasions. Annual Review of Ecology, Evolution, and Systematics, 47, 487-505. https://doi.org/10.1146/annurev-ecolsys-12141 $5-032050$

Martinez, J., Cogni, R., Cao, C., Smith, S., Illingworth, C. J., \& Jiggins, F. M. (2016). Addicted? Reduced host resistance in populations with defensive symbionts. Proceedings of the Royal Society B: Biological Sciences, 283(1833), https://doi.org/10.1098/rspb.2016.0778

Mattila, A. L. K., Duplouy, A., Kirjokangas, M., Lehtonen, R., Rastas, P., \& Hanski, I. (2012). High genetic load in an old isolated butterfly population. Proceedings of the National Academy of Sciences of the USA, 109(37), E2496-E2505. https://doi.org/10.1073/pnas.12057 89109

Meirmans, P. G., \& van Tienderen, P. H. (2004). GENOTYPE and GENODIVE: two programs for the analysis of genetic diversity of asexual organisms. Molecular Ecology Notes, 4, 792-794. https://doi. org/10.1111/j.1471-8286.2004.00770.x

Miller, E. J., Eldridge, M. D. B., Morris, K. D., Zenger, K. R., \& Herbert, C. A. (2011). Genetic consequences of isolation: island tammar wallaby (Macropus eugenii) populations and the conservation of threatened species. Conservation Genetics, 12(6), 1619-1631. https://doi. org/10.1007/s10592-011-0265-2

Montovan, K. J., Couchoux, C., Jones, L. E., Reeve, H. K., \& van Nouhuys, S. (2015). The puzzle of partial resource use by a parasitoid wasp. American Naturalist, 185(4), 538-550. https://doi. org/10.1086/680036

Murphy, D. D., Wahlberg, N., Hanski, I., \& Ehrlich, P. R. (2004). Introducing Checkerspots: taxonomy and ecology. In P. R. Ehrlich, \& I. Hanski (Eds.), On the wings of Checkerspots: a model system for population biology (pp. 17-33). Oxford University Press.
Nair, A., Fountain, T., Ikonen, S., Ojanen, S. P., \& van Nouhuys, S. (2016). Spatial and temporal genetic structure at the fourth trophic level in a fragmented landscape. Proceedings of the Royal Society B: Biological Sciences, 283(1831), https://doi.org/10.1098/rspb.2016.0668

Nei, M., Marutama, T., \& Chakraborty, R. (1975). The bottleneck effect and genetic variability in populations. Evolution, 29, 1-10. https:// doi.org/10.1111/j.1558-5646.1975.tb00807.x

O'Brien, E., Jorde, L. B., Rönnlöf, B., Fellman, J. O., \& Eriksson, A. W. (1988). Inbreeding and genetic disease in Sottunga, Finland. American Journal of Physical Anthropology, 75, 477-486. https://doi. org/10.1002/ajpa.1330750405

Ojanen, S. P., Nieminen, M., Meyke, E., Poyry, J., \& Hanski, I. (2013). Long-term metapopulation study of the Glanville fritillary butterfly (Melitaea cinxia): survey methods, data management, and long-term population trends. Ecology and Evolution, 3(11), 3713-3737. https:// doi.org/10.1002/ece3.733

O'Neill, S., Hoffman, A., \& Werren, J. (1997). Influencial passengers, inherited microorganisms and arthropod reproduction. Oxford University Press Inc.

Osborne, S. E., Iturbe-Ormaetxe, I., Brownlie, J. C., O'Neill, S. L., \& Johnson, K. N. (2012). Antiviral protection and the importance of Wolbachia density and tissue tropism in Drosophila simulans. Applied and Environment Microbiology, 78(19), 6922-6929. https:// doi.org/10.1128/AEM.01727-12

Pasek, J. E. (1988). Influence of wind and windbreaks on local dispersal of insects. Agriculture, Ecosystems \& Environment, 22(23), 539-554.

$R$ Core Team (2020). R: A language and environment for statistical computing. R Foundation for Statistical Computing. https://www.R-proje ct.org/.

Rokas, A., Atkinson, R. J., Brown, G. S., West, S. A., \& Stone, G. N. (2001). Understanding patterns of genetic diversity in the oak gallwasp Biorhiza pallida: demographic history or a Wolbachia selective sweep? Heredity, 87(Pt 3), 294-304. https://doi. org/10.1046/j.1365-2540.2001.00872.x

Sarhan, A., \& Kokko, H. (2007). Multiple mating in the Glanville fritillary butterfly: a case of within-generation bet hedging? Evolution, 61(3), 606-616. https://doi.org/10.1111/j.1558-5646.2007.00053.x

Sazama, E. J., Bosch, M. J., Shouldis, C. S., Ouellette, S. P., \& Wesner, J. S. (2017). Incidence of Wolbachia in aquatic insects. Ecology and Evolution, 7(4), 1165-1169. https://doi.org/10.1002/ece3.2742

Schuler, H., Koppler, K., Daxbock-Horvath, S., Rasool, B., Krumbock, S., Schwarz, D., \& Riegler, M. (2016). The hitchhiker's guide to Europe: the infection dynamics of an ongoing Wolbachia invasion and mitochondrial selective sweep in Rhagoletis cerasi. Molecular Ecology, 25(7), 1595-1609. https://doi.org/10.1111/mec.13571

Shaw, M. R., Stefanescu, C., \& Van Nouhuys, S. (2009). Parasitoids of European butterflies. In J. Settele, T. G. Shreeve, M. Konvicka, \& H. Van Dyck (Eds.), Ecology of butterflies in Europe. Cambridge University Press. http://www.eeb.cornell.edu/saskyavndata/uploa ds/pdf/shaw-stefanescu-vsvn-2009.pdf

Signor, S. (2017). Population genomics of Wolbachia and mtDNA in Drosophila simulans from California. Scientific Reports, 7(1), 13369. https://doi.org/10.1038/s41598-017-13901-3

Slarkin, M. (1985). Gene flow in natural populations. Annual Review of Ecology and Systematics, 16(1), 393-430. https://doi.org/10.1146/ annurev.es.16.110185.002141

Szucs, M., Melbourne, B. A., Tuff, T., \& Hufbauer, R. A. (2014). The roles of demography and genetics in the early stages of colonization. Proceedings of the Royal Society B-Biological Sciences, 281(1792), https://doi.org/10.1098/rspb.2014.1073

Urquia, D., Gutierrez, B., Pozo, G., Pozo, M. J., Espin, A., \& Torres, M. L. (2019). Psidium guajava in the Galapagos Islands: Population genetics and history of an invasive species. PLoS One, 14(3), e0203737. https://doi.org/10.1371/journal.pone.0203737

van Bergen, E., Dallas, T., DiLeo, M. F., Kahilainen, A., Mattila, A. L. K., Luoto, M., \& Saastamoinen, M. (2020). The effect of summer 
drought on the predictability of local extinctions in a butterfly metapopulation. Conservation Biology, 34(6), 1503-1511. https:// doi.org/10.1111/cobi.13515

van Nouhuys, S. (2005). Effects of habitat fragmentation at different trophic levels in insect communities. Annales Zoologici Fennici, 42(4), 433-447. https://www.jstor.org/stable/23735888

van Nouhuys, S. (2016). Diversity, population structure, and individual behaviour of parasitoids as seen using molecular markers. Current Opinion in Insect Science, 14, 94-99. https://doi.org/10.1016/j. cois.2016.02.006

van Nouhuys, S., \& Ehrnsten, J. (2004). Wasp behavior leads to uniform parasitism of a host available only a few hours per year. Behavioral Ecology, 15(4), 661-665. https://doi.org/10.1093/beheco/arh059

van Nouhuys, S., \& Hanski, I. (2002). Colonization rates and distances of a host butterfly and two specific parasitoids in a fragmented landscape. Journal of Animal Ecology, 71, 639-650. https://doi. org/10.1046/j.1365-2656.2002.00627.x

van Nouhuys, S., \& Hanski, I. (2005). Metacommunities of butterflies, their host plants and their parasitoids. In M. Holyoak, M. A. Leibold, \& R. D. Holt (Eds.), Metacommunities: Spatial dynamics and ecological communities (pp. 99-121). University of Chicago Press.

van Nouhuys, S., Kohonen, M., \& Duplouy, A. (2016). Wolbachia increases the susceptibility of a parasitoid wasp to hyperparasitism. Journal of Experimental Biology, 219(Pt 19), 2984-2990. https://doi. org/10.1242/jeb.140699

van Nouhuys, S., Niemikapee, S., \& Hanski, I. (2012). Variation in a hostparasitoid interaction across independent populations. Insects, 3(4), 1236-1256. https://doi.org/10.3390/insects3041236

Vavre, F., Fleury, F., Lepetit, D., Fouillet, P., \& Boulétreau, M. (1999). Phylogenetic evidence for horizontal transmission of Wolbachia in host-parasitoid associations. Molecular Biology and Evolution, 16(12), 1711-1723. https://doi.org/10.1093/oxfordjournals.molbev.a026084

Verne, S., Johnson, M., Bouchon, D., \& Grandjean, F. (2012). Effects of parasitic sex-ratio distorters on host genetic structure in the Armadillidium
vulgare-Wolbachia association. Journal of Evolutionary Biology, 25(2), 264-276. https://doi.org/10.1111/j.1420-9101.2011.02413.x

Wang, Z., Liu, Y., Shi, M., Huang, J., \& Chen, X. (2019). Parasitoid wasps as effective biological control agents. Journal of Intergrative Agriculture, 18(4), 705-715. https://doi.org/10.1016/S2095-3119(18)62078-7

Weinert, L. A., Araujo-Jnr, E. V., Ahmed, M. Z., \& Welch, J. J. (2015). The incidence of bacterial endosymbionts in terrestrial arthropods. Proceedings of the Royal Society B: Biological Sciences, 282(1807), 20150249. https://doi.org/10.1098/rspb.2015.0249

Zhou, W., Rousset, F., \& O'Neil, S. (1998). Phylogeny and PCR-based classification of Wolbachia strains using wsp gene sequences. Proceedings of the Royal Society B: Biological Sciences, 265(1395), 509-515. https://doi.org/10.1098/rspb.1998.0324

Zug, R., \& Hammerstein, P. (2012). Still a host of hosts for Wolbachia: analysis of recent data suggests that $40 \%$ of terrestrial arthropod species are infected. PLoS One, 7(6), e38544. https://doi. org/10.1371/journal.pone.0038544

\section{SUPPORTING INFORMATION}

Additional supporting information may be found online in the Supporting Information section.

How to cite this article: Duplouy, A., Nair, A., Nyman, T., \& van Nouhuys, S. (2021). Long-term spatiotemporal genetic structure of an accidental parasitoid introduction, and local changes in prevalence of its associated Wolbachia symbiont. Molecular Ecology, 30, 4368-4380. https://doi.org/10.1111/ $\underline{\text { mec. } 16065}$ 